Saudi Journal of Business and Management Studies Abbreviated Key Title: Saudi J Bus Manag Stud ISSN 2415-6663 (Print) |ISSN 2415-6671 (Online) Scholars Middle East Publishers, Dubai, United Arab Emirates Journal homepage: https://saudijournals.com/sibms

Review Article

\title{
Evaluate the Level of the Outputs of Administrative Training Programs Field Study of a Sample of Private Schools for Girls Sana'a Republic of Yemen
}

\author{
Halah A. Al-Wadi'ee ${ }^{1 *}$, Ayesha Farooq ${ }^{2}$ \\ ${ }^{1}$ Department of Business Administration, Aligarh Muslim University, Aligarh, Uttar Pradesh 202001, India \\ ${ }^{2}$ Professor, Department of Business Administration, Aligarh Muslim University, Aligarh, Uttar Pradesh 202001, India
}

DOI: $10.36348 /$ sjbms.2020.v05i04.001 $\quad$ | Received: 12.02 .2020 | Accepted: 19.02 .2020 | Published: 07.04 .2020

*Corresponding author: Halah A. Al-Wadi'ee

\section{Abstract}

There is no doubt that training plays an important and vital role in improving performance by acquiring the knowledge and skills necessary to accomplish the work [1]. The training is one of the life sciences that discuss the present and look to the future and address the shortcomings and mistakes, and help the individual to reformulate himself to adapt to the goals of renaissance and progress, and training is necessary and continuous activity over the life of the individual and activity inherent to the development of the individual and all levels of organizational levels It is not just a temporary solution to a problem facing the administration, continuous training is an investment in performance [2]. There have been many definitions of multiple vision of the researcher and those interested in this area. Among these definitions [3], training is defined as a planned process to modify the behavioral, cognitive and skill position through a learning experience to achieve effective performance in a range of activities, develop an individual's capabilities and satisfy current and future needs of the organization. This study aims to assess the level of outputs of training programs, not only to know their results, but to learn the next steps necessary to support the results of the training process. The problem was summarized in the deficiency of the level of outputs of training programs (reactions, learning, behavior, results). In private schools, and influenced by the demographic and organizational variables of individuals (age, qualification, administrative level, experience). The problem of the study was limited to training programs in the field of planning. The study concluded.

Keywords: Reactions, learning, behavior, results, training, planning, private schools for girls in Sana'a.

Copyright @ 2020: This is an open-access article distributed under the terms of the Creative Commons Attribution license which permits unrestricted use, distribution, and reproduction in any medium for non-commercial use (NonCommercial, or CC-BY-NC) provided the original author and source are credited.

\section{INTRODUCTION}

Zahra et al., [4] noted that training was the most important element in the management process, and that it had been practiced since ancient times through personal jurisprudence, and stated Nassazi [5], that it was agreed that training was of great importance in the field of human resources preparation. Rehabilitation, and thus the attention of organizations, which may lead to increased motivation and ability to work.

Buckley [6], Training has been defined as an organized process that requires reliance on effective scientific planning to achieve the desired objectives rather than a random activity. The experience and practice of the training activities resulted in basic principles such as inclusiveness, progressiveness, impact, modernization and development, quality [7]. Topno [8], pointed out that the evaluation system provides basic information that can be used to improve programs, to ensure that the instructions are applied well, that the components of the program are correct and that the skills that have been trained are the same as the skills actually required, and that it will increase the efficiency of the performance of individuals .The effectiveness of the training program is achieved not only through good planning and design, but also depends on the evaluation activity, which is inseparable from the rest of the training activities. These are 
evaluating the trainees, evaluating the training programs and evaluating the impact of training on the work. Kirk Patrick 's 1959 approach, on which the researcher relied on the research, is one of the most common and widely used approaches to training assessment. The researcher noted through her work with the civil and governmental schools of the Ministry of Education and the existence of deficiencies in the performance of administrative functions of individuals in those organizations, The fact that these organizations are an active partner of the government in the development process and due to the lack of skills and managerial experience of these cadres, so the training process became an urgent necessity, For example, the SFD report for 2006 reported that the training projects carried out by the Fund amounted to 66 projects nationwide for NGOs, private sector and government sectors at a total cost of $\$ 600,000$, The cumulative fund in the 446 training project was at a cost of $\$ 5$ million and the number was overstated 33000 individuals until the end of 2006 and through the work of the researcher with the authorities studied since 2001 in addition to their participation in several training courses for the researcher failed in the training outputs

\section{LITERATURE REVIEW}

The task or tasks of management personnel are not limited to the planning, selection and provision of the needs of the Organization. They also include broader topics such as the process of improving the efficiency of staff through effective training based on sound methodology at all stages, with the aim of preparing the workers of the organization to practice their work on a correct basis, and to achieve the production with the least effort and the lowest costs. Towler et al., [9] assumes that human resources are the most dynamic of all the organization's resources, and therefore they need great attention from the organization's management if human resources are to realize their full potential in their work. Section 10 of the (Labour Act 2003, Act 651) (Rights of a worker), states, "the rights of a worker include the right to be trained and retrained for the development of his work and to receive information relevant to his work". There are many types of training [10-13], and the organization can choose from training types, depending on the nature of the current activity, the expected activity, the expected changes in the technology and organization of the work of the organization and the nature of the labor market. Training types can be divided into three groups as shown in Table-1.

\begin{tabular}{|c|c|c|}
\hline Stages of employment & Type of jobs & Place \\
\hline $\begin{array}{l}\text { 1- } \begin{array}{l}\text { Direct the new employee } \\
\text { 2- }\end{array} \text { On-the-job training } \\
\text { 3- } \text { Training to identify knowledge and } \\
\text { skill } \\
\text { 4- Training for promotion and } \\
\text { transportation } \\
\text { 5- Training to prepare for retirement. }\end{array}$ & $\begin{array}{ll}\text { 1- } & \text { Vocational and } \\
& \text { technical training } \\
\text { 2- } & \text { Specialized training } \\
\text { 3- } & \text { Management training }\end{array}$ & $\begin{array}{ll}1- & \text { Within the company } \\
2- & \text { Outside the company } \\
\text { a- In a private company } \\
\text { b- In government programs }\end{array}$ \\
\hline
\end{tabular}

BARROW, 2015 [14], Sabaih, 2010 [15], Ferdous \& Razzak, 2012 [16], referred to four basic training phases.

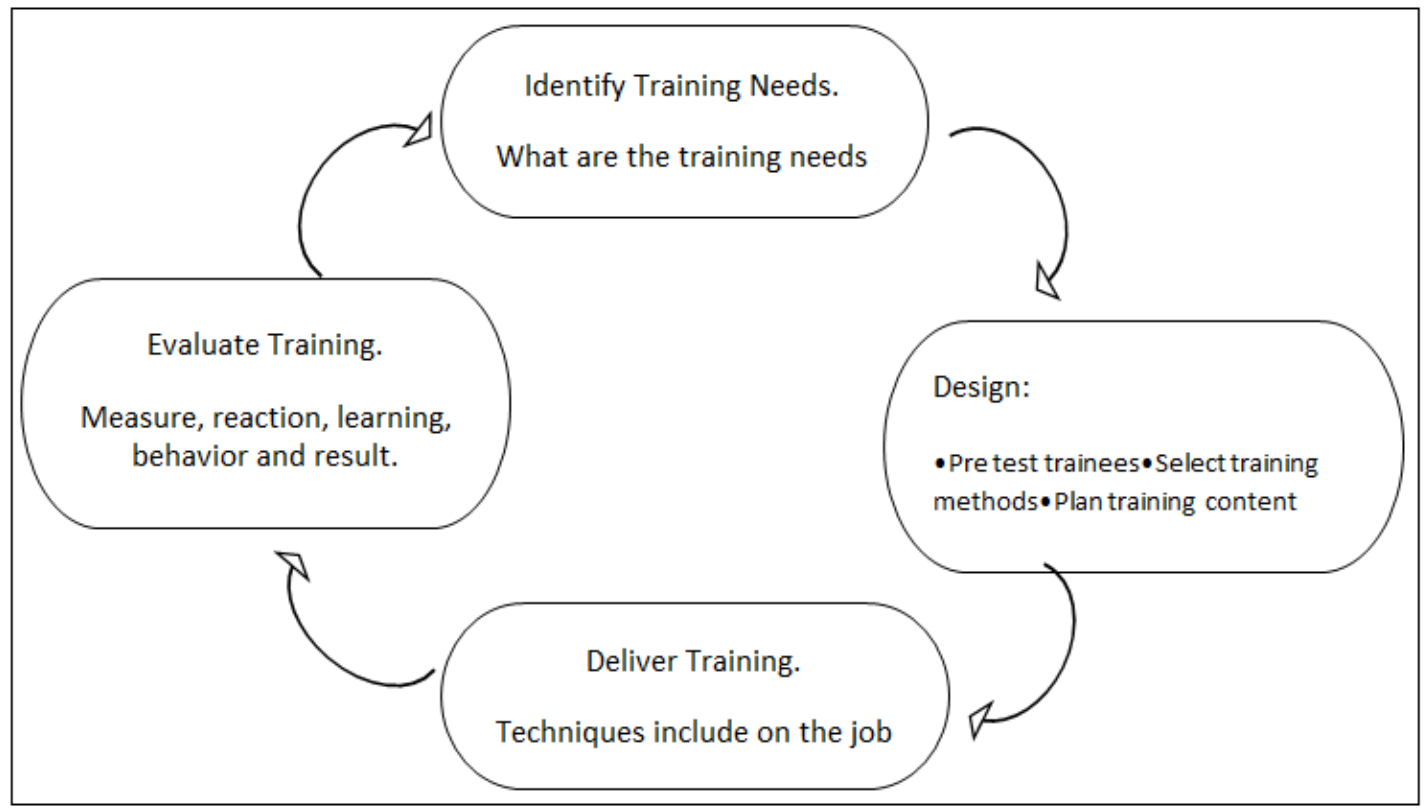


Figure-1 illustrates the logical and sequential stages of training, The cycle begins with an identification of training needs. The outcome of this step could result in either training or non-training solutions. If the 'needs' can be satisfied only through training, then the process will move on [17]

\section{Evaluation of Training Programs}

David [18], Borate [19], defines evaluation as a meaningful process to measure the efficiency of work and training programs, the amount achieved by the objectives of the training plan, and highlight the weaknesses and shortcomings, to avoid when planning those programs. There are a number of steps to plan the evaluation process [19]:
1. Identify strategies to be used to collect assessment data.

2. Identify who will collect assessment data and information.

3. Identify individuals and entities that will collect data and information assessment.

4. Determine when and where the data will be collected. 5-Determine how the information will return to us.

\section{Training Assessment Approaches}

Paull et al., [20, Winfrey [21], Haldar, K., \& Chandurkar [22], referred to the training assessment approaches as follows:

\begin{tabular}{|c|c|c|}
\hline & Name of the portlet & The most important differences \\
\hline 1 & Kirk Patrick entrance 1959 & $\begin{array}{l}\text { Identify four main assessment levels (reactions, } \\
\text { learning, behaviour, results). }\end{array}$ \\
\hline 2 & Parker's entrance 1973 & He added the group's performance dimension \\
\hline 3 & $\begin{array}{l}\text { Introduction to the study of the American company } \\
\text { for phones } 1979 A T \& T\end{array}$ & Add value outputs, training value in terms of cost \\
\hline 4 & Ciro entrance 1970 & $\begin{array}{l}\text { Address the phases of identify and selecting the } \\
\text { training program }\end{array}$ \\
\hline 5 & $\begin{array}{l}\text { Emco's entrance in Houston } \\
A P G\end{array}$ & He interested in the type of measurement and exporter \\
\hline
\end{tabular}

\section{Kirk Patrick Entrance 1959}

Donald Kirk Patrick has provided a reliable intellectual framework as a basis for determining the nature of the information to be collected in preparation for the assessment process, He identified four main levels of assessment [23-26] each with a question as follows:

\begin{tabular}{|l|l|}
\hline Level & Questions \\
\hline Reaction & Are participants happy with the program? \\
\hline Learning & Did you learn the participants of the program? \\
\hline Behavior & Did the participants adjust their behavior according to what they have learned? \\
\hline Result & Did the participants' modification of their behavior positively affect the results of their work? \\
\hline
\end{tabular}

\section{Obstacles to evaluation of training programs}

Kirkpatrick \& Kirkpatrick [27], Gomez [28, believes that the most important obstacles facing the evaluation of training programs lie in the following:

1. Lack of honesty and reliability of some assessment methods.

2. Trainees' resistance to the evaluation process.

3. Affected evaluation process is subjective.

4. The difficulty in proving that the change in the trainee behavior after training is due to the training itself.

5. Difficulty of measurement.

\section{Planning}

Ahmed said that the planning is the choice between different alternatives for the style of future work, both for the organization as a whole or part of them. Ahmed believes that planning is one of the basic administrative functions for any organization. It can be said that planning means setting the right goals, and then determine the appropriate means to accomplish these goals.

The goals are defined as the goals to be achieved by collective effort $[29,1]$. Goals have been categorized into long-term, medium-term and shortterm goals and classified according to the administrative level to strategic goals, operational and tactical goals and objectives directly goals.

The types of planning by administrative levels are shown in the following figure. 


\begin{tabular}{|l|l|l|}
\hline Administrative level & Types of planning & Time period \\
\hline $\begin{array}{l}\text { Senior Management } \\
\text {-Chairman of Board of Directors. } \\
\text {-General Director. } \\
\text {-Directors of public administration }\end{array}$ & Strategic planning & long-term \\
\hline $\begin{array}{l}\text { Middle Management. } \\
\text { Department Managers } \\
\text { Assistant Managers }\end{array}$ & Tactical planning & Medium term \\
\hline $\begin{array}{l}\text { Lower management } \\
\text { Supervisors } \\
\text { Team Leaders }\end{array}$ & Operational planning & short term \\
\hline
\end{tabular}

Ahmed believes that the planning process faces many obstacles, which can be divided into two types 1Obstacles resulting from individuals.2-Obstacles resulting from the process itself.

\section{The Plan}

Ahmed Certo [30] defined the plan as the main outcome of the planning process, Certo [30], said it was a list of purpose and action. The researcher believes that the plan is only a translation of the objectives that the organization seeks to achieve.

\section{Sample Search Variables}

Cognitive model illustrating the relationship between the independent variable and the dependent variable.

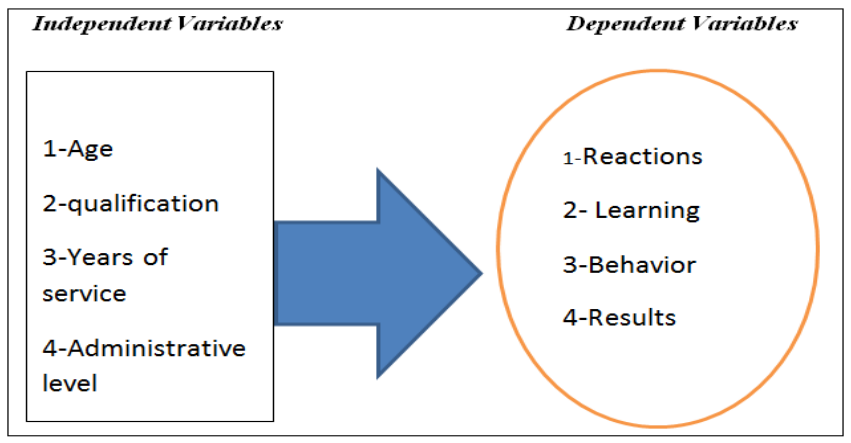

\section{RESEARCH METHODOLOGY}

The use of descriptive and analytical method for the study. The place of study was selected private schools for girls active in Sana'a, The sample identified individuals employed in private schools for girls who participated in planning training programs, The total number of 5 private schools for girls and 350 employees benefited from training programs from planning, After excluding staff who were not enrolled in the field of study, the sample was randomly selected from the study population.

The questionnaire was used, The questionnaire consisted of 29 words addressed to individuals.

The number of individuals who returned the questionnaire reached 160 questionnaires (14) were excluded because they were incomplete, to become the number of valid questionnaires (146).

The study tool consisted of (29) words as follows:

- Independent variables included demographic and organizational variables, which consisted of five basic elements (age, qualification, administrative level, and years of service)
- Dependent variables: It includes the variables represented by the outputs of the training programs.

CSS researcher for a questionnaire format was adopted, and was using a scale (Likert). Statistical data processing was done using the Statistical Package for Social Sciences (spss).

\section{Data Analysis Respondent's Profile}

Table-1: Age

\begin{tabular}{|l|l|l|l|}
\hline \multicolumn{2}{|c|}{ Demographic } & Frequency & Percent \\
\hline \multirow{3}{*}{ Age } & $20-30$ & 77 & 53.1 \\
\cline { 2 - 4 } & above 30 & 68 & 46.9 \\
\cline { 2 - 4 } & Total & 145 & 100 \\
\hline
\end{tabular}

Table-1 and Figure- 1 shows that ratio $(53,1)$ of the respondents were from the age group of 20-30, that ratio $(46,9)$ of the respondents were from the age group of above 30. It is clear that more than half of the young respondents may indicate their lack of practical experience and recent graduation, The age of employees in the private schools under study may be due to the following reasons: Career high turnover by many of these organizations Due to the lack of experience in the decision-makers there, It may be due to the desire of 
these organizations for high profit in the first place, Making them rely on low-paid cadres, Hence, we conclude that staff of these organizations need continuous training to address the gap between their current job requirements and their skills.

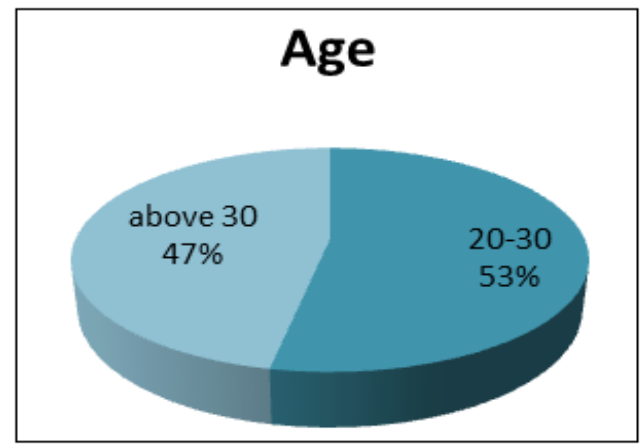

Fig-1: Age
Table-2: Education

\begin{tabular}{|l|l|l|l|}
\hline \multicolumn{2}{|l|}{ Demographic } & Frequency & Percent \\
\hline Education & secondary school & 13 & 9 \\
\cline { 2 - 4 } & graduate & 110 & 75.9 \\
\cline { 2 - 4 } & Other & 22 & 15.2 \\
\cline { 2 - 4 } & Total & 145 & 100 \\
\hline
\end{tabular}

Table-2 and Figure-2 shows that ratio $(75,9)$ of the respondents were from graduated, that ratio $(15,2)$ of the respondents were from other and that ratio the remaining of the respondents were from secondary school. This shows that three-quarters of the respondents are high qualification campaign and this shows their ability to understand the training programs, and then employ them in their working lives.

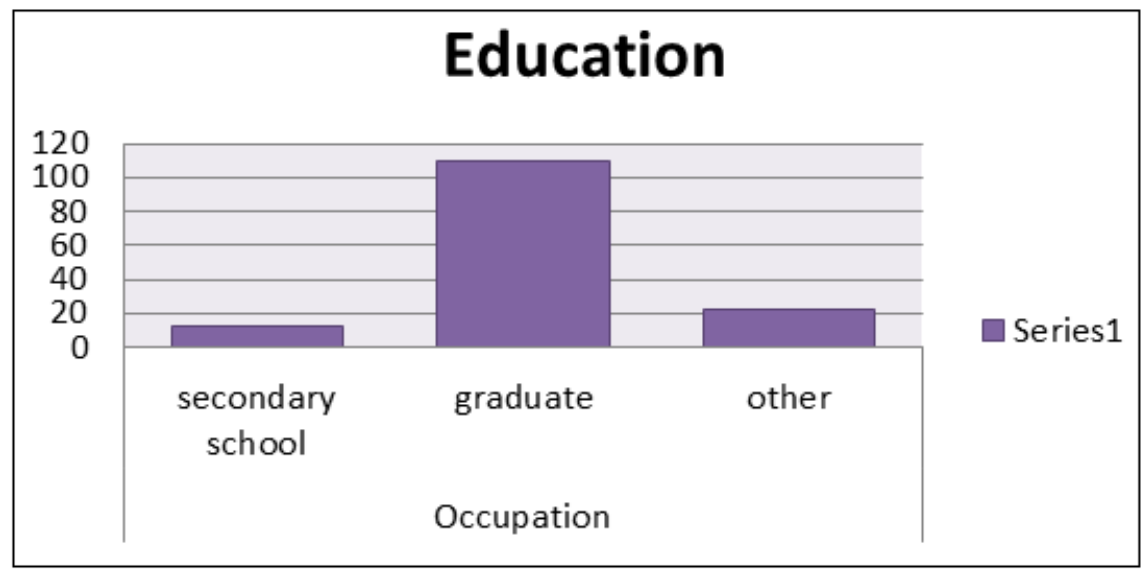

Fig-2: Education

Table-3: Experience

\begin{tabular}{|l|l|l|l|}
\hline \multicolumn{2}{|l|}{ Demographic } & Frequency & Percent \\
\hline Experience & 1-5 years & 52 & 35.9 \\
\cline { 2 - 4 } & 6-10 years & 61 & 42.1 \\
\cline { 2 - 4 } & above 10 & 32 & 22.1 \\
\cline { 2 - 4 } & Total & 145 & 100 \\
\hline
\end{tabular}

The Table-3 and Figure-3 shows that most of the respondents were rom the group 6-10 years (61 respondents) followed by 1-5 years (52 respondents). 32 of the respondents were from the group of above 10 . The lack of years of service for employees may be due to the same reasons in the age change represented by the instability of its staff (high job turnover). The low wage has a significant role in the leakage of cadres and this reinforces the explanation given when studying the variable age of the respondents so they are in dire need of training.

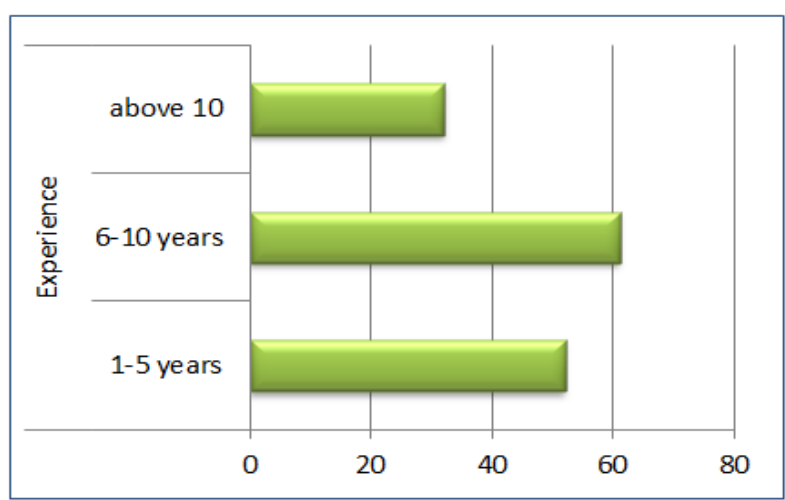

Fig-3: Experience

Table-4: Occupation

\begin{tabular}{|l|l|l|l|}
\hline \multicolumn{2}{|l|}{ Demographic } & Frequency & Percent \\
\hline Occupation & Administrative & 34 & 23.4 \\
\cline { 2 - 4 } & Teachers & 101 & 69.7 \\
\cline { 2 - 4 } & Specialist & 10 & 6.9 \\
\cline { 2 - 4 } & Total & 145 & 100 \\
\hline
\end{tabular}


Table-4 and Figure-4 shows that 101 of the respondents were from teachers, followed by administrative 34.10 of the respondents were from specialist.

From the results it is clear that there is a clear difference in favor of teachers, which may give an indication of the need for administrators and specialists for more attention and training compared to teachers, although this study was limited to disclose the level of outputs of training programs planning and is supposed to target mainly administrators. The fact that administrators are concerned primarily with this type of program is a key demand for the requirements of their work, emerges weakness in employment for optimal training opportunities among those actors weakens what might impact on the trainee and the organization as a whole

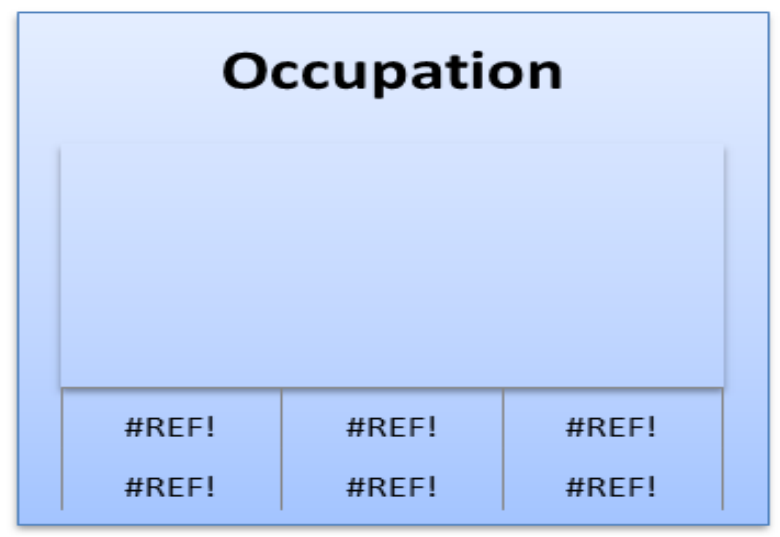

Fig-4: Occupation

\section{Reliability and validity}

Table-5 shows the Skew and kurtosis checked data normality and all variables were found to be distributed usually. If the skewness values fall within the+ 3 to- 3 range, this means normality of data. The result in Table 5shows that the findings of the skewness values are within +3 and -3 , and the figure from 7 to 14 shows that they are close to the line. Table- 5 gives the reliability evaluation to evaluate the level of logical consistency between multiple measurements. The reliability of any questionnaire can be tested using a Cronbach alpha test to check the internal consistency of the measured items. Scores nearer to 1 therefore indicate a greater degree of reliability. The table shows that Chronbach alpha's general group value for the different constructs used in the questionnaire. The list stated that the Chronbach value of all the constructs ranged from 0.815 to 0.7 . The general reliability is 0.7 , indicating the accuracy of the questionnaire.

Table-5: Reliability and validi

\begin{tabular}{|l|l|l|l|l|l|}
\hline \multirow{2}{*}{ Items } & Cronbach's Alpha if Item Deleted & \multicolumn{2}{l|}{ Skewness } & \multicolumn{2}{l|}{ Kurtosis } \\
\cline { 3 - 6 } & & Statistic & Std. Error & Statistic & Std. Error \\
\hline REACTION & 0.815 & -0.517 & 0.201 & 0.06 & 0.4 \\
\hline LEARNINIG & 0.772 & 0.312 & 0.201 & -0.002 & 0.4 \\
\hline BEHAVIOR & 0.70 & -0.11 & 0.201 & 0.043 & 0.4 \\
\hline RESULTS & 0.77 & -0.483 & 0.201 & 0 & 0.4 \\
\hline
\end{tabular}

\section{Descriptive Analysis}

Table-6: Descriptive analysis

\begin{tabular}{|l|l|l|l|l|l|}
\hline \multirow{2}{*}{ Items } & $\mathbf{N}$ & Minimum & Maximum & Mean & Std. Deviation \\
\cline { 2 - 6 } & Statistic & Statistic & Statistic & Statistic & Statistic \\
\hline REACTION & 145 & 1.00 & 3.33 & 2.3207 & .49226 \\
\hline LEARNINIG & 145 & 1.00 & 4.00 & 2.2910 & .66541 \\
\hline BEHAVIOR & 145 & 1.00 & 4.33 & 2.4575 & .66573 \\
\hline RESULTS & 145 & 1.00 & 4.57 & 3.0394 & .79298 \\
\hline
\end{tabular}

Table- 6 provides the outcomes for the research variables of a descriptive statistics. In the form of means, standard error and standard deviation, a descriptive statistics were calculated. In the research, the constructs were evaluated using a five-Likert scale anchored to the value of (1) representing the minimum and five representing the maximum. Table- 6 showed the outcomes that the mean value for 143 participants ranging from 2.3 to 3.03 , showing that most participants either highly likely agree or disagree on the statements 
of reaction, learning, behaviour and results. In addition, there are no differences between the mean score for the study variables

\section{ANOVA Test}

One way ANOVA was used among the differences among the means of level of training program and Age.

Table-7: Level of training program and Age

\begin{tabular}{|c|c|c|c|c|c|}
\hline Items & Sum of Squares & df & Mean Square & $\mathbf{F}$ & Sig. \\
\hline \multirow[t]{3}{*}{ REACTION } & .047 & 1 & .047 & .194 & .660 \\
\hline & 34.846 & 143 & .244 & & \\
\hline & 34.893 & 144 & & & \\
\hline \multirow[t]{3}{*}{ LEARNINIG } & .285 & 1 & .285 & .643 & .424 \\
\hline & 63.473 & 143 & .444 & & \\
\hline & 63.758 & 144 & & & \\
\hline \multirow[t]{3}{*}{ BEHAVIOR } & .137 & 1 & .137 & .308 & .580 \\
\hline & 63.684 & 143 & .445 & & \\
\hline & 63.821 & 144 & & & \\
\hline \multirow[t]{3}{*}{ RESULTS } & .003 & 1 & .003 & .004 & .947 \\
\hline & 90.547 & 143 & .633 & & \\
\hline & 90.550 & 144 & & & \\
\hline
\end{tabular}

According to the above Table-7 reaction $(\mathrm{F}=$ $.194)$, learning $(\mathrm{F}=.643)$, behaviour $(\mathrm{F}=.308)$, result $(\mathrm{F}=.947)$ were all not significant. Therefore, there is no significance difference. And the reasons were due to there is a lack of policy in schools about the process of employing the outputs of training programs, where private schools are interested in the recruitment of cadres in training programs without specifying clear mechanisms to employ those outputs and leave the subject to the employee's jurisprudence. Or may be due to changing staff and lack of stability in private schools, the reason that of these programs are not designed to address the functionality gap. The decision-makers in those schools should study the causes and address them to preserve their resources and address the imbalances in the training programs in terms of the trainer and the means and methods used in the training.. These percentages may not satisfy the aspirations of many of these schools, and at present the global trend towards quality, and the strength of competition in the work environment must be taken into account these ratio.

\section{Correlation Analysis}

Table- 8 presents that there is a positive correlation between age and (education, occupation, reaction, learning, behaviour and result). Table- 8 also shows that there is no correlation between (age and experience). Table- 8 also shows that education and occupation has a positive correlation with all items. Table- 8 presents that reaction has a positive correlation with (age, experience occupation, education). The table shows that there is no correlation between reaction with learning, behaviour and results. The lack of age differences may be attributed to the fact that two-thirds of the sample are in the same age group (20-30).

This explains the convergence in their selfassessment and the convergence of educational characteristics and have limited previous cumulative experience that this group is younger and do not have long years of service in private schools and may indicate deficiencies in the identification of training needs.

Table-8: Correlation Analysis

\begin{tabular}{|l|l|l|l|l|l|l|l|l|}
\hline \multicolumn{7}{|c|}{ Correlations } \\
\hline Items & Age & education & Experience & occupation & REACTION & LEARNINIG & BEHAVIOR & RESULTS \\
\hline Age & & & & & & & & \\
\hline Education & .104 & & & & & & & \\
\hline Experience & .000 & .779 & & & & & & \\
\hline occupation & .584 & .261 & .017 & & & & & \\
\hline REACTION & .660 & .129 & .780 & .483 & & & & \\
\hline LEARNINIG & .424 & .955 & .664 & .965 & .000 & & & \\
\hline BEHAVIOR & .580 & .478 & .167 & .871 & .000 & .000 & & \\
\hline Result & .947 & .795 & .376 & .150 & .000 & .000 & .000 & \\
\hline
\end{tabular}

\section{CONCLUSION}

Weak training impact on the organization mainly due to reasons related to the organization of the most important: a) High job turnover rate among the cadres of the organization this explains why a few years of service for employees in organizations.

b) Randomization in the nomination processes to join training programs. 
c) Weak ability of the organization in identifying training needs according to sound scientific methods.

The weakness of the skills of trainers about training methods and the use of modern training techniques. The training programs did not contribute to building the capacity of individuals in the organizations being studied as they are short and one-time training programs. Deficiencies in the use of means and methods of training were the most important reasons for low training outputs. Higher qualification and years of experience contributed in raising the training effect of the trainees, making them more positive and understanding. The time of implementation of training programs is not enough.

\section{REFERENCES}

1. AL-Ghushmi, M. S. (2008). Training Program outcomes Assessment a field study for a number of a sscociations and private institutions in sana,a capital-Republic of yemen.

2. Bentley, T. (1991). The Business of Training Achieving Success in Changing World Markets, London.

3. Reid, M. A., \& Barrington, H. (1992). Training interventions: Managing employee development. Institute of Personnel and Development.

4. Zahra, S., Iram, A., \& Naeem, H. (2014). Employee Training and Its Effect on Employees ' Job Motivation and Commitment : Developing and Proposing a Conceptual Model. IOSR Journal of Business and Management, 16(9), 60-68.

5. Nassazi, A. (2013). Effects Of Training On Employee Performance. Evidence from Uganda. http://theseus32-

kk.lib.helsinki.fi/bitstream/handle/10024/67401/T HESIS.pdf?sequence $=1$

6. Buckley, R. (1996). One - To - One Training Coaching Skills, London, Kegan Paul Ltd.

7. Ramesh, H. N., Ahmed, M., \& Alsabri, A. (2015). Training And Development Practices Of MNCs : An empirical study of selected MNCs in Sana s Yemen. Acme Intellects International Journal of Research in Management, Social Sciences \& Technology, 9(9), 2320-2793.

8. Topno, H. (2012). Evaluation of Training and Development: An Analysis of Various Models. Journal of Bussiness and Management, 5(2), 1622. www.iosrjournals.org

9. Towler, A., Watson, A., Surface, E. A., \& Towler, A. (2014). Signaling the importance of training. Journal of Managerial Psychology, 29(7), 829849.

10. Shibani, M. A. (2016). An Investigation Into Training Needs Analysis For Technical Staff Within Libyan Industrial Companies.

11. McClelland, S. B. (1993). Training needs assessment. Journal of European Industrial Training, 17(1).
12. Maya, A. S. D. S. E. (2009). Measurement of Training Effectiveness on Employee's Execution. Tishreen University Journal for Research and Scientific Studies -Economic and Legal Sciences Series, 31(1).

13. Shah, H., \& Gopal, R. (2012). Training needs analysis for bus depot managers at GSRTC. European Journal of Training and Development, 36(5), 527-543.

14. Barrow, O. (2015). Identifying Training Needs of Operating Core Staff: A Case of The Gambia Ports Authority and The Personnel (Issue November).

15. Sabaih, A. J. (2010). The perceived training needs of female head teachers compared with the training needs of male head teachers in the government public schools in Saudi Arabia.

16. Ferdous, T., \& Razzak, B. M. (2012). Importance of Training Needs Assessment in the Banking Sector of Bangladesh: A Case Study on National Bank Limited (NBL). International Journal of Business and Management, 7(10), 63-73.

17. Jamil, R. (2006). Raining Needs Analys Is (Tna) Practice S: A Surve Y Of The Top 1000 Com P Anie $\mathrm{S}$ in Malaysia.

18. David, L. (1991). Practical training services, $A$ practical Approach to group training, First published,London.

19. Borate, N. S. (2014). A Case Study Approach for Evaluation of Employee Training Effectiveness and Development Program Abstract: The International Journal Of Business \& Management, 2(6), 201-210.

20. Paull, M., Whitsed, C., \& Girardi, A. (2016). Applying the Kirkpatrick model: Evaluating an Interaction for Learning Framework curriculum intervention. Issues in Educational Research, 26(3), 490-507.

21. Winfrey, E. (2005). Kirkpatrick's four levels of evaluation. In Encyclopedia of educational technology (pp. 1-6). http://scholar.google.com/scholar?hl=en\&btnG=Se arch\&q=intitle:Kirkpatrick's+Levels + of + Evaluati on\#1

22. Haldar, K. \& Chandurkar, D. (2011). Using The Kirkpatrick Model of Training Evaluation. Sambodhl, 2(126), 22. www.southalabama.edu/coe/bset/johnson/660lectu res/Kirk1.doc

23. Sharma, D. (2016). Assessment of Evaluation Theory: Kirkpatrick Model in Opposition To Hamblin Model. International Journal of Science Technology and Management, 5(6), 194-204. http://www.ijstm.com/images/short_pdf/14662664 35_272ijstm.pdf

24. Saad, M., \& Mat, D. N. B. (2013). Evaluation Of Effectiveness of Training and Development: The Kirkpatrick Model. Asian Journal of Business and Management Sciences, 2(11), 14-24. http://www.ajbms.org/articlepdf/2ajbms20132112 
743.pdf

25. Ikramina, F., \& Gustomo, A. (2014). Analysis of Training Evaluation Process Using Kirkpatrick' S Training Evaluation Model At Pt. Bank Tabungan Negara. Journal of Business and Management, $3(1), 102-111$.

26. Soon Joo, G. (2017). The Kirkpatrick Model: The end is the beginning. https://www.kirkpatrickpartners.com/OurPhilosophy/The-Kirkpatrick-Model

27. Kirkpatrick, D. L., \& Kirkpatrick, J. D. (2009).
Evaluating Training Programs. In Evaluating training programs.

28. Gomez, A. K. A. Y. (2003). An Analysis of the Evaluation Practices of Employer-Sponsored Training In The Financial Services Industry.

29. Donna, M. M. (2005). Research and Evaluation in Education and Psychology. Edition 2end, The $U$. S. of America, Sage Publications Sinc.

30. Certo, S. C. (2003). Modern management, Pearson International Edition,Pearson Education. 